\title{
Evaluation Policy on Assistance Program Bidikmisi Higher Education in Private Kopertis Region Xii
}

\author{
Tahir Wasahua ${ }^{1} \nless$ \\ Yonny Koesmaryono ${ }^{2}$ \\ Illah Sailah ${ }^{3}$
}

${ }^{1,3}$ School of Business, Bogor Agricultural University, Indonesia Email:twasahua@gmail.com Tel:+6285284787356

${ }^{3}$ Emailisailah@yahoo.com

${ }^{2}$ Department of Communications Science and Community Development, Faculty of Human Ecology, Bogor Agricultural University, Indonesia

"Email:yonny_ipb@yahoo.com

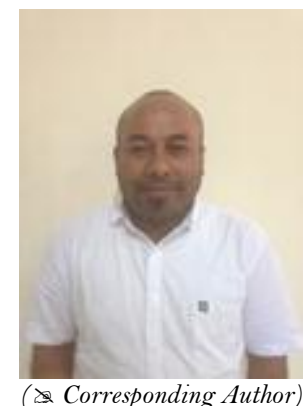

\begin{abstract}
One of the governments' policy through Directoral General of Learning and Student Affair, Ministry of Research, Technology and Higher Education in improving the access for new students namely the bidikmisi program. Program bidikmisi is a tuition fee subsidy program allocated to selected new students who possess excellent academic capability yet facing economic difficulties due to poor economical condition parents. bidikmisi program has been conducted annually in order to improve accesses to gain higher education. The purpose of this study is to reveal the impact of bidikmisi extension to the students' success in terms of student learning interest, learning attitude, motivation and academic achievement. Data collection technique used in this study were descriptive qualitative and quantitative, by spreading questionnaire to bidikmisi receiver which consisted of 246 students of year 2013, 2014 and 2015 on 28 higher education in private under kopertis regional XII. Data analyzed using descriptive analysis and multiple regression. The study result indicates that the intrinsic characteristic for admission year of bidikmisi program, gender, age, school origin, area origin, parents' educational background and parents' income partially did not influence significantly to students' attitude and behaviour; however, parents' occupation gave a real impact towards students' attitude and behaviour. bidikmisi program management and the characteristic environment of college students partially gave a significant influence to students' learning interest, learning attitude, motivation in order to attain academic achievement.
\end{abstract}

Keywords: Bidikmisi, Evaluation, Education, Descriptive analysis, Multiple regression.

Citation | Tahir Wasahua; Yonny Koesmaryono; Illah Sailah (2018). Evaluation Policy on Assistance Program Bidikmisi Higher Education in Private Kopertis Region Xii. Journal of Education and e-Learning Research, 5(1): 1-7. History:

Received: 21 November 2017

Revised: 3 January 2018

Accepted: 5 January 2018

Published: 8 January 2018

Licensed: This work is licensed under a Creative Commons Attribution 3.0 License (oc)

Publisher:Asian Online Journal Publishing Group
Contribution/Acknowledgement: All authors contributed to the conception and design of the study.

Funding: This study received no specific financial support.

Competing Interests: The authors declare that they have no conflict of interests.

Transparency: The authors confirm that the manuscript is an honest, accurate, and transparent account of the study was reported; that no vital features of the study have been omitted; and that any discrepancies from the study as planned have been explained.

Ethical: This study follows all ethical practices during writing.

\section{Contents}

1. Introduction

2. Methodology

4. Conclusion.

References. .2 3 7 


\section{Introduction}

Bidikmisi program is one of the program established by The Republic of Indonesia Government since 2010 in accordance to a hundred-day United Indonesia Cabinet 2nd. This education fee subsidy allocated to senior high school/vocational school/MA graduates who achieved excellent performance yet coming from poor families who could not afford to enrolled their education a higher education. At first, the bidikmisi only given to new students in public universities, but then in 2012 the scholarship was also given to new students in private universities.

As for the regulations used as the base of the policy in the extension of the tuition fee initially by: [1] Ordinance No. 20 Year 2003 regarding national education system article 5 verse 12 (1.c) and (1.d); [2] Government Regulation No. 48 Year 2008 regarding educational funding, section 5 article 27 verse 1 and 2 which stated that the fulfillment of students' rights as mentioned in versed 1 conducted by giving: (a) Scholarship to excellent achievement students; (b) subsidy or education tuition exemption ; and/or (c) Interest free loan that must be paid back after graduation and/or obtaining a job; (4) The regulation of The Education and Culture Minister No. 96 Year 2014 regarding the implementation of education tuition bidikmisi.

The bidikmisi program objectives are as follow: (a) Improving learning motivation and achievement of future students specially those who face economic difficulties; (b) Improving access and learning opportunities in higher education institution for un-afforded students but having excellent academic potentials; (c) Giving educationfee subsidy to future/students who fulfill the requirements to enrolled their education in the diploma/undergraduate program until completed on time; (d) Improving students' achievement, both in the curricular field, co-curricular and extra curricular; (e) Emerging the side effect for the students and future students to always improving performance and being competitive; ( $\mathrm{f}$ ) Utter independent and productive graduates who also possess social concern, to enable them taking part in the termination of poverty chain and community development/implementation guidelines mission-aim scholarship (Kemenristekdikti, 2016).

According to Assegaf (2014) Implementation of policies is the application of actions that give impact to an action that is desired or not by the parties concerned in achieving the desired goals. Implementation of policy is one of the important variables that affect the success of a policy in solving public problems. Whereas bidikmisi program is a very noble subsidy with its motto "Reaching Hope of Poverty Chain Termination". Apparently this program was not only terminate poverty chain, but also raising the dignity, self value, prestige or social status of missionaim scholarship receiver (Herawati, 2016).

Based on the above explanation, the writer was interested to conduct further study regarding the evaluation of bidikmisi program for private higher education institution in co-ordination area 12. As for the purpose of this study was to reveal the influence of bidikmisi extension over the students' success learning achievement viewed from their attitude and behaviour.

Since 2015, bidikmisi program organized by directoral general of learning and Student Affair of The Ministry of Research, Technology and Higher Education. bidikmisi program would be delivered ever since the future students determined had passed the admission selection exam to university and confirmed as the bidikmisi receiver for undergraduate and associate degree (D4) of maximum 8 semesters and diploma program of maximum 6 semesters. Since 2016, the amount of education fee scholarship was Rp6.300.000 (Six million and three hundred thousand Rupiah) per semester; which consists of Rp2.400.000 (Two million and four hundred thousand Rupiah) per student per semester; living cost subsidy Rp650.000 (Six hundred and fifty thousand Rupiah) per student per month or Rp3.900.000 (Three million and nine hundred thousand Rupiah) per student per semester.

According to Rahayu and Suwanda (2015) the purpose of the extension of bidikmisi was to enliven hopes to poor community yet possessed high academic potentials to enrolled their education to higher education, besides that this program hopefully will also producing human resources who would be capable to play a role in alleviating poverty and community development. These objectives shows so much hope of the government in alleviating poverty issues as the efforts in improving education quality.

This study aims to analyze the influence of the variables of intrinsic characteristics, the characteristics of bidikmisi program management and students' environment characteristic through the attitude and behaviour of bidikmisi receiver.

\section{Methodology}

The study took place in private higher education institution accross Maluku and North Maluku area. The responden were the receiver of bidikmisi program students in 2013, 2014 and 2015, with an active status in odd semester consisted of 246 students spread over 28 higher education in private under kopertis regional XII.

Data collection technique used in this study was the questionnaire through a series of question asked to the respondents, distributed through Google Form directly responded by the receiver of the bidikmisi program receiver.

Data were analyzed using the descriptive statistic method with qualitative and quantitative approach. The quality of the study instruments measured using three analysis tools, as follow:

1. Validity Test, to correlized the score of the responds of each questions with the amount of variable score; and relaibility test to measure the consistency of the assessment result if they were tested twice or more.

2. Descriptive analysis in order to attain a deep description of each indicator variables.

3. Multiple Linier Regression Analysis, used to measure the influence between two or more variables. The analysis of the influencing factors that impacted the behaviour of mission aim scholarship receiver students viewed based on their learning interest, attitude, motivation and academic achievement. The multiple regression test were conducted over three study variables, namely (1) Intrinsic characteristic; (2) bidikmisi program characterisitic management; and (3) Students' environment characteristic. 


\section{Discussion and Result}

\subsection{The Influence of Intrinsic Characteristic to the Behaviour of Bidikmisi Program Receiver} Students

The intrinsic characteristics in this study consist of year of acceptance of bidikmisi program, gender, age, school origin, regional origin, parent education, parent's job and parent's income. The number of respondents in the study amounted to 246 students receiving the bidikmisi program in which its distribution based on intrinsic characteristics as follows:

Table-1. Persentage of respondent based on the intrinsic characteristic

\begin{tabular}{l|l|l|l|l}
\hline No. & Intrinsic Characteristic & Category & Amount & Percentage (\%) \\
\hline 1 & Admission Year & 2013 & 67 & 27,2 \\
\hline & & 2014 & 77 & 31,3 \\
\hline & & 2015 & 102 & 41,5 \\
\hline 2 & Gender & Male & 87 & 35,4 \\
\hline & & Female & 159 & 64,6 \\
\hline 3 & Age & $17-19$ Years old & 53 & 21,5 \\
\hline & & $20-22$ Years old & 168 & 68,3 \\
\hline 4 & School Origin & $23-26$ Years old & 25 & 10,2 \\
\hline & & High School & 167 & 67,9 \\
\hline & & Vocational High School & 60 & 24,4 \\
\hline 5 & Area Origin & MA & 19 & 7,7 \\
\hline & \multicolumn{2}{|l}{ Maluku } & 85 & 34,6 \\
\hline Source: Data processing result, 2017 & North Maluku & 161 & 65,4 \\
\hline
\end{tabular}

Table 1 shows that the bidikmisi program receiver students in 2015 have the largest percentage of $41.5 \%$. The study result indicates that the admission year of bidikmisi program was not significantly influence the attitude and behaviour of college student, with a significant value of 0.07 or the $t$-count $1.823<1.970$. This means that the characteristic of the bidikmisi program receiver students group shows no correlation to the learning interest, attitude, motivation and academic achievement.

Table 1 indicates that the female students attain larger percentage of $64.6 \%$ compared to male students. The study result using the t-test on gender characteristic stated that the gender unsignificantly effected to the students' attitude and behaviour, with a significant value of 0.171 or t-count of $-1.372<1.970$. In this matter, the bidikmisi program received by both male and female gender group gave a not so great influence to their learning interest, attitude, motivation and academic achievement. Based on Table 1, the students' age group of $20-22$ years old have the biggest percentage of $68.3 \%$ compared to those other age group both $17-19$ years old age group and $23-26$ years old age group. The study result indicated that the age characteristic not signoficantly influence the students' attitude and behaviour with a significant value of 0.369 or t-count of $-0.900<1.970$. Meaning that the group of bidikmisi program receiver students aged between 17 to 26 years old possess an unwell time of study management discipline to their learning interest, attitude, motivation and academic achievement.

The study result of school and area origin variable have a non significant influence to the students' attitude and behaviour, namely the school origin variable with a significant value of 0.671 or t-count $0,426<1.970$, as well as the area origin variable value of 0.758 or t-count $0.308<1.970$. Meaning that the group of students originally came from different school and area with a different educational background either high school, vocational school or MA, accross Maluku and North Maluku have no difference over their learning interest, attitude, motivation and academic achievement. Table 1 indicates that the group student originally came from high school dominated the extension of bidikmisi program as much as $67.9 \%$, however the area origin of students group from North Maluku dominated the percentage result of $68.3 \%$.

Table-2. Respondent percentage based on parents educational background

\begin{tabular}{l|l|l|l|l|l}
\hline \multirow{2}{*}{ No. } & Parents Educational & Father & Mother & \multicolumn{3}{l}{} \\
\cline { 3 - 6 } & Background & Amount & Percentage (\%) & Amount & Percentage (\%) \\
\hline 1 & No school & 13 & 5,3 & 17 & 6,9 \\
\hline 2 & Elementary school or equivalent & 65 & 26,4 & 91 & 37,0 \\
\hline 3 & Junior High School or equivalent & 44 & 17,9 & 56 & 22,8 \\
\hline 4 & High School or equivalent & 106 & 43,1 & 69 & 28,0 \\
\hline 5 & Diploma Degree & 7 & 2,8 & 6 & 2,4 \\
\hline 6 & Bachelor Degree & 11 & 4,5 & 7 & 2,8 \\
\hline & Total & 246 & 100 & 246 & 100 \\
\hline
\end{tabular}

Source: Data processing result, 2017

Table-3. Respondent percentage based on parents occupation

\begin{tabular}{l|l|l|l|l|l}
\hline No & Parents & Father & Mother & \\
\cline { 3 - 6 } & Occupation & Amount & Percentage (\%) & Amount & Percentage (\%) \\
\hline 1 & Government Official & 13 & 5.3 & 9 & 3.7 \\
\hline 2 & Employees of Private Sector & 11 & 4.5 & 5 & 2.0 \\
\hline 3 & Entrepreneur & 37 & 15.0 & 19 & 7.7 \\
\hline 4 & Farmer & 137 & 55.7 & 105 & 4.2 .7 \\
\hline 5 & Fisherman & 12 & 4.9 & 1 & 0.4 \\
\hline 6 & $\begin{array}{l}\text { Other (retired, labour, driver, teacher, peddicab driver, } \\
\text { street sweeper, housewive, teacher, village office staff, etc) }\end{array}$ & 28 & 11.4 & 35 & 14.2 \\
\hline 7 & Not working & 8 & 3.3 & 72 & 29.3 \\
\hline & Total & 246 & 100 & 24.6 & 100 \\
\hline
\end{tabular}


Table-4. Respondent percentage based on parents income

\begin{tabular}{l|l|l|l}
\hline No & Parents Income & Amount & Percentage (\%) \\
\hline 1 & No Income & 23 & 9.3 \\
\hline 2 & Rp 250.000 & 34 & 13.8 \\
\hline 3 & Rp 250.000 - Rp 500.000 & 67 & 27.2 \\
\hline 4 & Rp 500.000 - Rp 750.000 & 42 & 17.1 \\
\hline 5 & Rp 750.000 - Rp 1.000.000 & 29 & 11.8 \\
\hline 6 & Rp 1.000.000 - Rp 1.250.000 & 16 & 6.5 \\
\hline 7 & Rp 1.250.000 - Rp 1.500.000 & 8 & 3.3 \\
\hline 8 & Rp 1.500.000 - Rp 1.750.000 & 4 & 1.6 \\
\hline 9 & Rp 1.750.000 - Rp 2.000.000 & 3 & 1.2 \\
\hline 10 & Rp 2.000.000 - Rp 2.250.000 & 3 & 1.2 \\
\hline 11 & Rp 2.250.000 - Rp 2.500.000 & 5 & 2.0 \\
\hline 12 & Rp 2.500.000 - Rp 2.750.000 & 3 & 1.2 \\
\hline 13 & Rp 2.750.000 - Rp 3.000.000 & 3 & 1.2 \\
\hline 14 & Rp 3.000.000 - Rp 3.250.000 & 3 & 1.2 \\
\hline 15 & Rp 3.500.000 - Rp 3.750.000 & 3 & 1.2 \\
\hline \multicolumn{2}{l}{ Sotal } & 246 & 100 \\
\hline Source: Data processing result, 2017 & \\
\hline
\end{tabular}

Table 2 and Table 3 presented parents' social conditions such as their educational background, occupation and income describing social condition of the parents of mission aim scholarship program receiver students. This conditions indicates how the scholarship receiver students actually came from unwealthy/poor family background with a very low income, which described by their parents' educational background, occupation and income. The mission aim scholarship receiver students were originally came from social economic condition of middle class and below. As it is known, the requirements to obtain mission aim scholarship that the students had to come from poor/unwealthy families, which earned less than Rp3.000.000 (three million Rupiah) per family (father and mother) per month. On Table 4 can be seen that there are receiver students' parent who earned more than Rp3.000.000 per month, however if it were devided by the number of family members (number of children) would earned nothing more than Rp750.000 (seven hundred and fifty thousand Rupiah) per person. This means that they were still qualified to received the scholarship.

Based on the study result by t-test described that parents' educational background unsignificantly influence the students' attitude and behaviour which can be identified with the indicators of learning interest, attitude, motivation and academic achievement, where the siginificant value of 0.646 or t-count valued $-0.460<1.970$. In this study the parents' educational background have no correlation towards educational degree and academic achievement of the scholarship receiver students. As it was described in Table 1, the fathers' educational background of high school or equivalent graduates only reach $43.1 \%$ and mothers' education of only elementary school or equivalent graduates as low as $37.0 \%$. Most of the mission aim scholarship receiver students' parents were having a low grade of educational background, thus it influence the students' knowledge, this concludes that parents poverty level effected by their level of education. Through this scholarship, unlike the parents who were mostly not having a proper education, the children hoped to obtain a higher level of education than the parents, in hope that they would have a better future and quality of life. Although the students came from un-educated or low level education parents, their spirit of learning and their passion to perform the best achievement are very high, with an excellent learning interest, attitude, motivation and academic achievement, hopefully this could bring a family pride and raise their family social status in the future.

According to the t-test calculation, parents' occupation were giving a real impact on the students' attitude and behaviour, where the indicators are namely their learning interest, attitude, motivation and academic achievement. It is known that the parents' occupation significantly influence the indicators of 0.646 or t-count value $-2.031<$ 1.970. Meaning the parents are playing an important role and a big contribution towards their children education, how the parents worked hard to support the childrens' dreams and future have becoming a great motivation to them. Although some parents were only farmers, still encourage students to perform the best academic achievement. The group of farmers children were encourage to prove their parents and community that by obtaining a high level of education would change their family social status in the future. Table 1 presented that majority of parents were small farmers, namely the fathers as much as $55.7 \%$ and mothers of $42.7 \%$. Therefore, parents are playing an important role on encouraging and can be a positive example to their children in having a better future.

However, the study result of parents' income, presented an unsignificant influence between parents' income to the students' attitude and behaviour, with a significant value of 0.200 or t-count value $1.284<1.970$. The parents' income factor can both gave a good or bad impact towards students academic achievement. Parents with great income tend to pamper their children by supporting all their educational needs, however low income parents or barely afford were having a great difficulties fulfilling their children educational needs. This matter did not occur for mission aim scholarship receiver students, because to be able to obtain the scholarship, the students must actually coming from poor or unwealthy families yet having a good academic achievement. Based on Table 1, majority of students' parent income were below Rp3.000.000,- as much as $97.6 \%$ and only $2.4 \%$ parents with an income over Rp3.000.000. Due to their majority occupation as only small farmers, thus they gained uncertain income and facing a great difficulties in fulfilling the students' educational needs. However the low income of parents actually relevance to the students' academic performance, it could boost their motivation to perform the best achievement in their studies. Through mission aim scholarship program, had ease the burden of the low income parents, whose now could stop worrying about their chilrdren education expenses, due to its subsidy provided by the government that support the students educational needs up until they complete their studies in the university. Hopefully the bidikmisi encourage the receiver students to maintain performing the best academic achievement. The higher learning interest, attitude, motivation of the students, the better performance they attain 
in academic achievement. Supports and encouragement from parents and family are motivation for bidikmisi receiver students to do well in their academic performance.The result of this study were in accordance to research by Saleh (2014) that stated parents factor was very relevance to a students success in their study. The high and low of parents education level, the big or small income, enough or not the parents' attention and guidance, in harmony or not the relationship between parents, are all the factors that influence learning achievement of students; and Astuti et al. (2016) also stated that students' characteristic factor had a positive impact on students' academic achievement, meaning the better the characteristic of student, the better their academic achievement.

\subsection{The Influence of Mission Aim Program Management towards Scholarship Receiver Students' Attitude and Behaviour}

The influence of mission aim program management in this study are presented in three indicators, namely the punctuality of bidikmisi acceptance, the adequacy of living cost and the effectiveness of living cost. The time punctuality of bidikmisi acceptance assessed to see whether the scholarship distributed by the government could be accepted every semester on time; the adequacy of living cost to figure out the conformity of the living cost received by the respondents, viewed from the respondents' needs and benefits; and the effectiveness of the living cost utility whether they were utilized for academic or non academic necessity. The indicators of mission aim program management are presented in the Table 5 .

Table-5. Respondents' perception towards the characteristic of mission aim management

\begin{tabular}{l|l|l|l}
\hline No & Indicator & Average & Interpretation \\
\hline 1 & Punctuality of bidikmisi acceptance & 3.43 & High \\
\hline 2 & Adequacy of living cost & 4.21 & Very High \\
\hline 3 & Effectiveness of living cost & 2.85 & Low \\
\hline & Total Average Score & 3.66 & High \\
\hline
\end{tabular}

Source: Data processing result, 2017

As shown on Table 5, the students' perception value towards the characteristic of mission aim program management based the indicator of punctuality of mission aim program acceptance score on the average of 3.43 were being in the "high" criteria. This indicates that the time of the living cost distribution process had always been punctual. Meanwhile, based on the indicator of adequacy of living cost the score was on an average of 4.21; being at the category of "very high". This indicates that the living cost accepted by the students was very adequate to fulfill their daily needs during the study period at the private university. However, based on the indicator of effectiveness of the living expenses utility only score on an average of 2.85 criterized as "low". This indicates that the utility of living cost by the student, were not effective with the students' necessity whether they are academic or non academic needs. Due to the accepted living cost utility, not only for academic necessity but also used for non academic needs such as supporting parents' expenses or paying family debt or any other needs.

The multiple regression test used to measure the influence of characteristic mission aim program management variable towards students' attitude and bahaviour. The test resulted variable t-test X2 that the characteristic of mission aim program management was significantly influence to the attitude and behaviour of the scholarship receiver student, with a significant value of 0.024 or $\mathrm{t}$-count value $2.278>\mathrm{t}$-table value of 1.970 . The utility of the living cost besides for academic needs was also used for non academic necessity, the utility of living cost should be suitable to students' needs in supporting their daily needs during the study period at the private university, the management of bidikmisi relevance to attitude and behaviour of students. Students must plan the utility of the living cost in accordance to the stipulated conditions, when the living cost used for academic purposes, then the learning result and achievement would be better. Supporting the students living cost and education fee certainly giving positive impact on their attitude and behaviour. The attitude and behaviour of students consist of learning interest, attitude, motivation and academic achievement. With the existance of bidikmisi in terms of living cost and education fee received directly by the students, was proven to give positive influences towards the success of students' academic achievement. The higher students' learning interest, attitude and motivation which will be indicated in terms of GPA would produce a better academic achievement and instilling a sense of responsibility among students to give the best performance and efforts to finish their education in accordance to the stipulated time. Rahayu and Suwanda (2015) stated that the utility of bidikmisi pattern related to the students' life style. The students who tend to have a luxurious life style would always felt lack of fund, on the other hand, the students with a simple life style would always felt sufficient and able to manage the fund properly. The result of this study suitable to the previous research conducted by Waskito and Azizah (2013) pronounced that the distribution of scholarship were positively influence the learning motivation towards students of Economic Faculty of Yogyakartas' Public University.

\subsection{The Influence of Student Environment Characteristic towards Attiitude and Behaviour of Bidikmisi Receiver Student}

The influence of student environment characteristic can be identified in three indicators which are the family environment, academic environment and community environment. Family environment described interaction and moral support to respondents in undertaking their education at the university; academic environment illustrated the interraction of respondents with the head of private universities, lecturers and academic staff in developing their knowledge in campuss, involvement in an organization and obtaining academic achievement; while the community environment decribed the students' involvement in the activities outside of campuss, dedication to the community, and sosialize with the community. These social characteristic indicators of the bidikmisi receiver presented in Table 6. 
Table-6. Respondents' perception towards student environment characteristic

\begin{tabular}{l|l|l|l}
\hline No & Indicator & Average & Interpretation \\
\hline 1 & Family Environment & 3.60 & High \\
\hline 2 & Academic Environment & 3.05 & Adequate \\
\hline 3 & Community Environment & 3.26 & Adequate \\
\hline & Total Average Score & 3.25 & Adequate \\
\hline
\end{tabular}

Table 6 presented that the perception value of student environment characteristic based on the indicator of family environment gain an average score of 3.60 was on the criteria "high". Meaning that the moral support of family member in terms of encouragment and trust giving a highly positive impact for student. Moral support from both of the parents would encourage student, motivate them and improve their self confident in undertaking the education or facing any difficulties during their study in the university. The indicator of academic environment gain an average score of 3.05 being under tha category of "adequate". This ilustrated that the support of academic society in improving and assist student attain academic achievement. The support of academic society, lecturers and head of private universities in developing science and encourage student undertaking their education enables them to finish at the right period of study time. While the indicator of community environment gain an average score of 3.26 with the criteria "very high". It means that community environment was contributive factor in their self development by accustomed their sensitivity of over viewing the surrounding environment, being able to cooperate with any society of various discipline, occupying them selves in the social intercourse and adaptive to live amongst community. In this study, community environment apparently gave more benefits for student in developing their capability as well as contribute positive impact in their learning process.

Multiple regression test to measure the influence of the student environment characteristic variable towards students' attitude and behaviour, producing t-test result which shows that the value of variable $\mathrm{X} 3$ student environment characteristic significantly influence to students' attitude and behaviour with a significant value of 0.000 or t-count value $24.862>$ t-table value 1.970 . The factor of family environment, academic environment and community environment gave positive impact to academic achievement of students, apparently the family environment becomes the source of motivation and moral support for students in attaining academic achievement. Academic environment was the place to see the interraction of student with lecturers, academic community and students' involvement in extracurricular and co-curricular activities. The bidikmisi receiver students possess a certain rightfully pride due to the attention and optimum support given in the learning process by academic community in gaining their academic achievement. They also have a moral responsibility to maintain their feasibilty and becoming a role model to other student who did not supported by bidikmisi. Meanwhile, the community environement gave its own part in developing the student outside of campuss, more benefits that the students obtain in community environment were likely in terms of self development by accustomize their sensitivity of over viewing the surrounding environment, co-operating and conduct collaboration with any society of various discipline, in a way of interract with other people, occupying them selves in the social intercourse and adaptive to live amongst community. This study result in accordance to the previous reserach by Saleh (2014) who stated that family factor, campuss environment (academic) and active involvement in an organization significantly influence student in a positive way towards students' academic achievement; Also study result by Herlambang et al. (2012) stated family and social environment partially giving a significant influence to the personality of bidikmisi program receiver student of Jember University in 2012. However, this study result was not suitable with Astuti et al. (2016) research which pronounce that external factor gave no influence to students' achievement, because BUD and mission aim program receiver student did not determined by their external factors; however, Mardiyanti (2014) stated that academic environment and students' environment influence un significantly to the certainty of study completion.

Being the reciever of bidikmisi program is a rightfully pride and bring its own happiness to the student who receive it. However, on the other hand, they also have a moral responsibility. They must take the responsibility, prooving their feasibility and becoming a role model among other wealthy students (Nasir, 2016).

\subsection{Managerial Implication}

The study result which was found, the variables of bidikmisi program gave influences to receiver students also as indicators with certain perception of each variables. These indicators should be the center of attention by the stakeholders running the bidikmisi program. The following implications founded in this study should be consideration to Kopertis Regional XII and higher education in Kopertis Region XII it self as the implementer of bidikmisi program.

1. It is necessary to have a more selective selection to bidikmisi program receiver students to aim the rightfully targeted future receiver, also it is urgent to conduct a fair verification of data in accordance to the requirements pronounce in mission aim guidelines.

2. The factor bidikmisi program management gave a positive influence to students, therefore the leader in head of private universities must keep paying attention of its management in private universities level and contionously communicate with the Ministry of Research, Tecnology and Higher Education as well as to Co-ordinator of higher education in Kopertis Region XII regarding the management of bidikmisi program. Particularly always searching for current information in the management ammendment and new guidelines that might be established by the Ministry.

3. The student environment characteristic factor gave influence towards learning interest, motivation the facand learning achievement of the students, therefore of private universitieshopefully could pay more attention to students' learning achievement and involved them in the soft skills development through a variety of activities.

4. Increasing the involvement of students who receive bidikmisi assistance in every student activities organized by Kopertis Region XII and optimize the guidance by the academic and student affairs to students to always provide encouragement, motivation in taking education to complete the study on time 


\section{Conclusion}

From the study of bidikmisi program receiver students in higher education in Kopertis Region XII, the conclusion are as follow:

1. The real influencing factors to bidikmisi program receiver students' attitude and behaviour in the intrinsic characteristic are as follow: the indicator of parents' occupation, that eventhough most of the parents were working only as small farmers, could give encouragement and positive impact towards mission aim program receiver student to achieve the best performance both in academic and non academic field. This matter could encourage the receiver students in changing their family's economical and social status in the future. However the other indicators namely year of admission, gender, age, school origin, area origin, parents' educational background and income did not influence the bidikmisi receiver students' attitude and behaviour.

2. The study also found that the characteristic of mission aim program management that dominately influence the receiver students' attitude and behaviour viewed by the respondents perception are as follow: the adequacy of living cost, the deployment of bidikmisi to students in terms of living cost and tuition fee were very beneficial. The living cost directly received were used in various necessity during the students' undertaking the education in the private university up until the completion of their study.

3. Based on the analysis to mission aim program management variables, the other factor that influence the receiver students' attitude and behaviour were the management of living cost. The living cost received by the students were used to fullfil both their academic and non academic needs, besides that, it could also used to help supporting their poor parents.

4. The characteristic of students environment that mostly influence the bidikmisi program receiver students' attitude and behaviour viewed by respondents' perception was the family. The moral support and words of encouragement given by the family were able to motivate the students in attaining the best academic achievement.

5. Based on the analysis, the variable of the characteristic of students environment were very influence to the bidikmisi program receiver students' attitude and behaviour. Supports from family, civitas academic and surrounding community gave a bigger yet undirect influence for students in attaining the best performance both academic and non academic achievement.

\section{References}

Assegaf, F.A., 2014. Implementation of Permendiknas No. 48 of 2008 on educational funding for outstanding and underprivileged students. Journal of Policy and Education Development, 2(2): 113-119.

Astuti, F.B., U. Sumarwan and I. Qayim, 2016. The role of student engagement to student academic achievement of region delegation scholarship and mission-aim at Bogor Agricultural University, (Thesis), Bogor: Bogor Agricultural University.

Herawati, 2016. Mission-aim terminates the chain of poverty, Bahana Belmawa [Article]. Jakarta: Directorat General of Learning and Student Affair.

Herlambang, D., S. Setyanti and E. Prajitiasari, 2012. The influence of family environment and social environment to entrepreneur interest of mission-aim student batch 2012 with personality variable as the intervening variable. Jember: Jember Public University.

Kemenristekdikti, 2016. Ministry of research, technology and higher education, the manual book of mission-aim education fee scholarship implementation. Jakarta: Directorat General of Learning and Student Affair.

Mardiyanti, 2014. The effectiveness of the scholarship program in improving student achievement. Bogor (ID): Bogor Agricultural University. Master Thesis.

Nasir, 2016. Mission-aim terminating the chain of poverty, Bahana Belmawa. Jakarta: Directorat General of Learning and Student Affair.

Rahayu and Suwanda, 2015. The pattern of mission-aim scholarship usage by student of social science faculty surabaya public university batch 2011. Journal of Moral and Citizenship Studies, 03(03): 1160-1174.

Saleh, 2014. The influence of motivation, family factor, campuss environment and active organizing to academic achievement. Journal Phenomenon, 4(2): 109-141.

Waskito and Azizah, 2013. The effect of granting students scholarship on the learning motivation of the student of the economics faculty of Yogyakarta State University in 2012. Journal PELITA, 3(1): 12-22. 